\title{
Generol Enitnology \\ Selectivity and sublethal effect of botanical extracts on adults of Trichogramma pretiosum Riley (Hymenoptera: Trichogrammatidae)
}

\author{
Joanina Gladenucci ${ }^{\circledR \oplus}$, José Carlos de Almeida Pernambuco Filho ${ }^{2 \oplus}$, \\ Regiane Cristina de Oliveira Freitas Bueno ${ }^{2 \oplus}$ \& Filipe Pereira Giardini Bonfim ${ }^{2}$
}

1. Universidade Federal de Lavras, Lavras, MG, Brazil. 2. Universidade Estadual Paulista (UNESP), São Paulo, SP, Brazil.

\section{EntomoBrasilis 13: e871 (2020)}

Edited by:

Anderson Gonçalves da Silva

Article History:

Received: 02.ix.2019

Accepted: 20.v.2020

Published: 24.vii.2020

$凶$ Corresponding author:

Joanina Gladenucci

७ jogladenucci@gmail.com

Funding agencies:

$\Delta$ Without funding declared

\begin{abstract}
The objective was to assess the selectivity and sublethal effect of botanical extracts on adults of Trichogramma pretiosum Riley (Hymenoptera: Trichogrammatidae). Plant species used: Rosmarinus officinalis L., Mikania glomerata Spreng., Varronia curassavica Jacq., Chenopodium ambrosioides L., Vermonia polyanthes Spreng., Plectranthus amboinicus Spreng., Tetradenia riparia Codd., Artemisia absinthium L., Cymbopogon citratus Stapf. Plant material were reared in laboratory and leaves collected during the morning were used to prepare the extracts as following: $100 \mathrm{~g}$ of leaves from each plant were macerated and immersed in $300 \mathrm{~mL}$ of triple-extracted methyl alcohol and evaporated on rotavapor. Then, $250 \mathrm{mg}$ of crude extract was diluted in $1000 \mathrm{~mL}$ of water. The experimental design for selectivity was done in randomized blocks with five repetitions, following a standardized protocol of the International Organization for Biological Control (IOBC) and accordingly classified. In sublethal effect, the design was completely randomized with twenty repetitions, where the eggs exposed to parasitism were sprayed with the treatments. In both experiments the control was twofold (water and chlorpyrifos). Regarding selectivity, the botanical extracts of M. glomerata, C. ambrosioides, $V$. polyanthes, P. amboinicus, A. absinthium and C. citratus were classified as slightly harmful (class 2), chlorpyrifos as moderately harmful (class 3 ). In the evaluation of sublethal effects, the botanical extracts of C. ambrosioides and C. citratus initially presented reduced number of parasitized eggs, reduction in total parasitized eggs and female longevity. It can be concluded that $C$. citratus botanical extract has small selectivity and causes sublethal effects on T. pretiosum adults.
\end{abstract}

Keywords: Biological Control; Botanical insecticides; Entomology; Integrated Pest Management; Parasitoid. of plants can be obtained and be used as insecticides, allowing the expansion of agroecological products (SILvA et al. 2017). However, one of the limitations of botanical insecticides usage is the lack of knowledge about the effect of these compounds on the benefic fauna of agroecosystems (Vendramim \& Castiglioni 2000), especially in regard to pest's natural enemies. The majority of works dealing with pest management by using botanical products highlight that the usage of these substances must be compatible with other pest control tactics, especially biological control. However, some researches have been demonstrating the existence of variations in the effects caused by botanical products on natural enemies (RIBEIRo et al. 2009).

Several natural or botanical products are commonly related as causers of negative effects in Trichogramma spp. One of the most famous examples is the Neem (Azadirachta indica A. Juss), which is sprayed in host-eggs, resulting in significant reduction of the parasitism (Olivelra et al. 2003; GonçalvesGervásio \& Vendramim 2004; Hohmann et al. 2010; Silva 2010). The Azidrachtin is the main compound among the secondary compounds. However, several other triterpenoids are found, such the meliantriol, limonene, oderatone, as well as more than 150 other compounds already isolated, which may present synergy with insecticides, enhancing its action (SIDIQUI et al. 2003; MORGAN 2009). 
However, despite the benefits above-mentioned, these plants have the disadvantage of lacking data related to phytotoxicity, persistency and their effects in benefic organisms (Costa et al. 2004; Aguiar-Menezes 2005). Plant effects can be measured by checking if there is lowering in feeding, inhibition of chitin production, growth interruption, changings in ecdysis, reduction in fecundity, morphological deformations, increasing in death rate and repellency and toxicity to men and domestic animals (Medina et al. 2003; Mossini \& Kemmelmeier 2005; Ndione et al. 2007; Morgan 2009).

One of the biggest challenges in the usage of plants as bioinsecticides is the elaboration of formulas which are able to keep their ingredients active through longer periods of time in the target body (NeRIO et al. 2009), aside from getting information about biologic control agents and the effects of plant-based products.

Thus, it is demonstrated the need for development of new studies about the effect of natural products in agents of biological control, as new products are still arriving at the market. In this context, the aim of this work was to investigate the selectivity and sublethal effects of botanical extracts in adults of Trichogramma pretiosum Riley.

\section{MATERIAL AND METHODS}

The experiment was conducted at the Plant Protection Department of the Faculty of Agronomic Sciences, Universidade Estadual Paulista "Júlio de Mesquita Filho" (FCA/UNESP), Botucatu Campus, São Paulo, Brazil, under controlled conditions ( $12 \mathrm{~h}$ of photophase, $25{ }^{\circ} \mathrm{C}$ e $70 \%$ of relative humidity).

Plant collect and botanical extract preparation. The extracts were obtained at the Laboratory of Medicinal Plants of the Horticulture Department of the Faculty of Agronomic Sciences, Universidade Estadual Paulista Júlio de Mesquita Filho" (FCA/UNESP). Leaves were collected during morning, reared under organic management at Medicinal Garden and then taken to the laboratory. A hundred grams of fresh material of each plant were macerated in methanol (immersed in 300 $\mathrm{mL}$ of methyl alcohol for 24,48 and $72 \mathrm{~h}$, in triple extraction, resulting in $900 \mathrm{~mL}$ of methanolic extract). The solvent was evaporated in a rotatory evaporator (Quimis) and the crude extract diluted in the proportion of $1000 \mathrm{~mL}$ to $250 \mathrm{mg}$ of distilled water, then conserved in a glass recipient of amber coloration.

Rearing maintenance of $T$. pretiosum. Adults of T. pretiosum were kept in a four liters recipient, under controlled conditions of temperature $\left(25 \pm 2{ }^{\circ} \mathrm{C}\right)$, relative humidity $(70 \pm 10 \%)$ and photophase (14 h), fed with crude honey chunks; fresh eggs of Ephestia kuehniella Zeller (Lepidoptera: Pyralidae), glued to a double-sided tape which was glued over a coated paper, were available during $24 \mathrm{~h}$ to stimulate parasitism. Past this time period, the cards were individualized in new recipients until the larvae emerged from the eggs, starting a new rearing cycle.

Treatment selection. The botanical extracts of Rosmarinus officinalis L., Mikania glomerata Spreng., Varronia curassavica Jacq., Chenopodium ambrosioides L., Vermonia polyanthes Spreng., Plectranthus amboinicus Spreng., Tetradenia riparia Codd., Artemisia absinthium L., Cymbopogon citratus Stapf used in the bioassays were chosen based on previous results obtained by testing in second instar nymphs of Spodoptera frugiperda (Smith) (Lepidoptera: Noctuidae). The tests consisted of pulverizing the extracts on the nymphs by using a Potter spray tower ${ }^{\circledR}$ (by contact) and by incorporating the extracts in the artificial diet (by ingestion). Thus, the criteria of the plant species selection were the insecticide effect of the plants, by contact and ingestion, in the above-mentioned pest insect, in the concentration of $1000 \mathrm{~mL}$ of crude extract to $250 \mathrm{~mL}$ of distilled water, as previously described. The active ingredient chlorpyrifos, an insecticide of the organophosphate chemical group, was used as positive control (as recommended by IOBC) and distilled water as negative control.

Application of botanical extracts in selectivity and sublethal bioassays. The experimental design was made in randomized blocks with eleven treatments and five repetitions for selectivity and entirely randomized with 20 repetitions for sublethal effect. The Potter spray tower ${ }^{\circledR}$ was pre-calibrated to pulverize $250 \mathrm{~L} \mathrm{ha}^{-1}$, with pressure varying between 5-7 psi and deposition of $1.75 \pm 0.25 \mathrm{mg}$ $\mathrm{cm}^{2}$, measured in analytical balance, following the standard procedure suggested by the IOBC. For the pulverization, a volume of $1.13 \mathrm{~mL}$ of each treatment was separated in Eppendorfs $®$.

Cages for selectivity assessment. The cages used followed the IOBC suggestion, made with aluminum frames juxtaposed with screws. Three sides of the cage have entirely tightened orifices, assuring the imprisonment of the subject and allowing for gas exchange (HASSAN et al. 2000). On the fourth side there are two openings: one made to introduce the egg-cards and another used to release the parasitoids in the cages. The top and bottom sides are sealed with glass plates and interconnected by a hose-system connected to a pressure pump used to remove air by suction.

Selectivity. The top and bottom glass-plates of the cages were built to expose the subjects to the pulverizations. Prior to the exposure, cards with parasitized eggs ( \pm 600 eggs) were individualized in Duran ${ }^{\circledR}$ tubes to obtain a mean of 200 females per cages (HASSAN et al. 2000). The individuals of 24 hours-old were exposed to the treatments. After the colonization of the interior of the cages, cards of $6.25 \mathrm{~cm}^{2}$ with fresh eggs of $E$. kuehniella ( \pm 1.200 eggs) were made available to stimulate parasitism, during the period of 24,48 and 72 h. After 96 hours, the cages were disassembled and the eggcards collected and individualized by date and treatment in plastic bags to posterior analyses. The parasitism $(P)$ was analyzed with the equation $P=$ number of parasitized eggs I number of offered eggs $\times 100$. The viability and parasitism reduction in relation to the negative control was assessed by the efficiency equation: $E(\%)=(1-$ (mean percentage of the treatment / mean percentage of the treatment control) $x$ $100)$, where: $E(\%)$ is the percentage reduction of the benefic capacity of the parasitoid (Sterk et al. 1999; MANzoni et al. 2006). Thus, the results were classified according to mean reduction, as suggested by the IOBC standards: class 1 innocuous ( $\mathrm{E}<30 \%)$; class 2 - slightly harmful (30 $\leq \mathrm{E} \leq 79 \%)$; class 3 - moderately harmful $(80 \leq \mathrm{E} \leq 99 \%)$; class 4 - harmful (E > 99\%) (HASSAN 1992).

Sublethal effects. Females of T. pretiosum were individualized in a Duran $®$ tube based on antenna structure (QUERINO \& ZUCCHI 2011) and fed with a drop of honey. During their life-time, the females were daily offered cards of $0.25 \mathrm{~cm}^{2}$ with fresh eggs ( \pm 180 eggs) of E. kuehniella, pulverized with the treatments, to observe the sublethal effects of those females which did not suffer lethal effect. The egg-cards were labeled and stored to posterior analyses. The total number of parasitized eggs and longevity of parasitoids was analyzed, although the sublethal effects of the treatments may affect the insect's physiology and interfere in the analyzed parameters (DESNEUX et al. 2007).

Statistical analyses. The results were analyzed by an Analyses of variance (ANOVA) and the means compared with a Tukey's test with $5 \%$ of significance with the software SISVAR 5.6. 


\section{RESULTS AND DISCUSSION}

Selectivity of botanical extracts on adults of $T$. pretiosum. The usage of selective products, be chemicals or botanical extracts, contribute to the efficiency of the natural and applied biological control, being less aggressive to the benefic entomofauna. However, the botanical active ingredients are composed by a complex of substances, which can have insecticide effects and thus may toxically act in the insect's body, leading to feeding inhibition, difficulty in growth, development, reproduction and changing in behavior (AgUIARMenezes 2005). Hence, selective insecticides are more suitable to be used in pest control with less impact in the populations of natural enemies (Bueno \& BUeno 2012).

The highest parasitism rates occurred on the first day afterwards emergence (D.A.E.), when adults of T. pretiosum entered in contact with pulverized surfaces. However, the extracts of $M$. glomerata, C. ambrosioides, $V$. polyanthes, $P$. amboinicus, $A$. absinthium and $C$. citratus caused alterations of the parasitism, being classified as slightly harmful (class 2 ). The extract of $C$. citratus caused alteration of the parasitism (16.18), as well as reduction (76.44\%), numbers close to those of the positive control (chlorpyrifos), which is considered to be moderately harmful (class 3) (Table 1).
On the second D.A.E., the extracts of R. officinalis, M. glomerata, C. ambrosioides and $V$. polyanthes induced the reduction of the parasitism and were classified as slightly harmful (class 2 ), as well as the extract of $C$. citratus, with a parasitism proportion of 6.74 and reduction of $78.99 \%$, numbers which are also close to those of chlorpyrifos, with 1.83 and $94.3 \%$ respectively (Table 2 ).

On the third D.A.E., the extracts of M. glomerata, C. ambrosioides, V. polyanthes, C. citratus and chlorpyrifos were classified as slightly harmful (class 2) (Table 3). The remaining treatments did not cause changings or reductions of the parasitism.

Plants of C. citratus have therapeutic properties, such as bactericide and fungicide, and are also popularly used against lices (LorenzI \& Matos 2008). These features are possible due to the presence of terpenes, like the citral (a mix of neral and geranial isomers), myrcene, citronellol and nerol (CARRICONDE et al. 1996). Tests with three different concentrations (1\%, 5\% and $10 \%$ ) of lemon grass essential oil in Thyrinteina arnobia Stoll (Lepidoptera: Geometridae) resulted in insecticide effect, causing $100 \%$ of mortality in subjects submitted to concentrations of 5\% and 10\% (SOAREs et al. 2011). This lethal effect in T. arnobia may explain the low amount of selectivity found in T. pretiosum. The chlorpyrifos is commonly included

Table 1. Parasitism and viability on the $1^{\text {st }}$ day after emergence (D.A.E.) in adults of Trichogramma pretiosum (Hymenoptera:Trichogrammatidae).

\begin{tabular}{|c|c|c|c|c|c|c|}
\hline \multirow{2}{*}{ Treatments } & \multicolumn{3}{|c|}{$1^{\text {st }}$ D.A.E } & \multicolumn{3}{|c|}{$1^{\text {st }}$ D.A.E } \\
\hline & $\mathbf{P}^{1}$ & $\% E^{3}$ & $\mathrm{C}^{4}$ & $\mathrm{~V}^{2}$ & $\% \mathrm{E}^{3}$ & $\mathrm{C}^{4}$ \\
\hline R. officinalis & $54.64 \pm 0.71 \mathrm{~b}$ & 20.43 & 1 & $95.22 \pm 0.51 a b$ & 4.47 & 1 \\
\hline M. glomerata & $36.85 \pm 1.59 \mathrm{~d}$ & 46.34 & 2 & $96.73 \pm 1.42 a b$ & 2.96 & 1 \\
\hline V. curassavica & $52.20 \pm 1.94 \mathrm{~b}$ & 23.98 & 1 & $78.34 \pm 5.58 \mathrm{c}$ & 21.41 & 1 \\
\hline C. ambrosioides & $36.73 \pm 2.51 \mathrm{~d}$ & 46.52 & 2 & $99.09 \pm 0.05 \mathrm{a}$ & 0.11 & 1 \\
\hline V. polyanthes & $42.70 \pm 2.80 \mathrm{c}$ & 37.52 & 2 & $95.05 \pm 1.15 a b$ & 4.65 & 1 \\
\hline P. amboinicus & $44.60 \pm 2.43 c$ & 35.07 & 2 & $97.61 \pm 0.35 a$ & 2.08 & 1 \\
\hline T. riparia & $51.12 \pm 4.89 \mathrm{~b}$ & 25.57 & 1 & $95.53 \pm 1.99 a b$ & 4.16 & 1 \\
\hline A. absinthium & $43.76 \pm 2.90 \mathrm{c}$ & 36.27 & 2 & $90.63 \pm 3.77$ b & 9.07 & 1 \\
\hline C. citratus & $16.18 \pm 0.59$ e & 76.44 & 2 & $93.15 \pm 3.10 a b$ & 6.55 & 1 \\
\hline Distilled water & $68.67 \pm 0.93$ a & 0 & 1 & $99.67 \pm 0.09 \mathrm{a}$ & 0 & 1 \\
\hline chlorpyrifos & $6.23 \pm 0.85 f$ & 90.92 & 3 & $79.01 \pm 6.56 \mathrm{c}$ & 20.74 & 1 \\
\hline
\end{tabular}

Means \pm SE with the same letter in the column do not differ by Tukey's test $(P>0,05)$. ${ }^{1}$ Parasitism; ${ }^{2}$ viability; ${ }^{3}$ Reduction in viability capacity; ${ }^{4}$ Classes: 1 - innocuous ( $\mathrm{E}<30 \%), 2$ - slightly harmful $(30 \leq \mathrm{E} \leq 79 \%), 3$ - moderately harmful $(80 \leq \mathrm{E} \leq 99 \%)$ and 4 - harmful $(\mathrm{E}>99 \%)$.

Table 2. Parasitism e viability on the $2^{\text {nd }}$ day after emergence on adults of Trichogramma pretiosum (Hymenoptera: Trichogrammatidae).

\begin{tabular}{|c|c|c|c|c|c|c|}
\hline \multirow{2}{*}{ Treatments } & \multicolumn{3}{|c|}{$2^{\text {nd }}$ D.A.E ${ }^{1}$} & \multicolumn{3}{|c|}{$2^{\text {nd }}$ D.A.E ${ }^{1}$} \\
\hline & $\mathbf{P}^{2}$ & $\% E^{3}$ & $\mathrm{C}^{4}$ & $\mathbf{V}^{2}$ & $\% E^{3}$ & $\mathrm{C}^{4}$ \\
\hline R. officinalis & $19.91 \pm 0.43 d$ & 37.92 & 2 & $92.96 \pm 0.58 \mathrm{a}$ & 6 & 1 \\
\hline M. glomerata & $14.17 \pm 0.86 \mathrm{e}$ & 55.82 & 2 & $94.07 \pm 1.42 \mathrm{a}$ & 4.88 & 1 \\
\hline V. curassavica & $25.74 \pm 2.11 \mathrm{~b}$ & 19.74 & 1 & $93.19 \pm 6.19 \mathrm{a}$ & 5.77 & 1 \\
\hline C. ambrosioides & $16.30 \pm 1.36 \mathrm{e}$ & 49.19 & 2 & $97.67 \pm 1.53 \mathrm{a}$ & 1.31 & 1 \\
\hline V. polyanthes & $16.33 \pm 1.09 \mathrm{e}$ & 49.07 & 2 & $94.55 \pm 1.65 \mathrm{a}$ & 4.4 & 1 \\
\hline P. amboinicus & $22.89 \pm 1.25 \mathrm{bcd}$ & 28.65 & 1 & $87.78 \pm 3.74 a b$ & 11.26 & 1 \\
\hline T. riparia & $23.54 \pm 2.49 \mathrm{bc}$ & 26.61 & 1 & $97.12 \pm 0.45 \mathrm{a}$ & 1.79 & 1 \\
\hline A. absinthium & $22.90 \pm 1.40 \mathrm{~cd}$ & 28.6 & 1 & $95.84 \pm 2.05 \mathrm{a}$ & 3.09 & 1 \\
\hline C. citratus & $6.74 \pm 0.90 \mathrm{f}$ & 78.99 & 2 & $91.60 \pm 6.59 a b$ & 7.39 & 1 \\
\hline Distilled water & $32.07 \pm 2.44 \mathrm{a}$ & 0 & 1 & $96.31 \pm 3.21 \mathrm{a}$ & 0 & 1 \\
\hline chlorpyrifos & $1.83 \pm 0.16 \mathrm{~g}$ & 94.3 & 3 & $81.34 \pm 11.72 b$ & 23.1 & 1 \\
\hline
\end{tabular}

Means \pm EP followed by the same letter in the column do not differ between themselves in Tukey's test $(P>0,05) .{ }^{1} P a r a s i t i s m ;{ }^{2}$ viability; ${ }^{3}$ Reduction in viability capacity; ${ }^{4}$ Classes: 1 - innocuous ( $\left.E<30 \%\right), 2$ - slightly harmful $(30 \leq \mathrm{E} \leq 79 \%), 3$ - moderately harmful $(80 \leq \mathrm{E} \leq 99 \%)$ and 4 - harmful ( $\mathrm{E}>99 \%)$. 
Table 3. Parasitism e viability on the $3^{\text {rd }}$ day after emergence on adults of Trichogramma pretiosum (Hymenoptera: Trichogrammatidae).

\begin{tabular}{|c|c|c|c|c|c|c|}
\hline \multirow{2}{*}{ Treatments } & \multicolumn{3}{|c|}{$3^{\text {rd D.A.E }}$} & \multicolumn{3}{|c|}{$3^{\text {rd D.A.E }}$} \\
\hline & $\mathbf{P}^{1}$ & $\% \mathrm{E}^{3}$ & $\mathrm{C}^{4}$ & $\mathbf{V}^{2}$ & $\% \mathrm{E}^{3}$ & $\mathrm{C}^{4}$ \\
\hline R. officinalis & $7.98 \pm 0.20 \mathrm{~cd}$ & 25.43 & 1 & $87.69 \pm 0.41 \mathrm{~cd}$ & 10.53 & 1 \\
\hline M. glomerata & $6.20 \pm 0.45$ e & 42.1 & 2 & $94.83 \pm 2.43 \mathrm{ab}$ & 3.26 & 1 \\
\hline V. curassavica & $8.50 \pm 0.16 c$ & 20.5 & 1 & $84.31 \pm 5.85 d$ & 13.98 & 1 \\
\hline C. ambrosioides & $5.30 \pm 0.27 f$ & 50.51 & 2 & $90.69 \pm 2.86 \mathrm{bcd}$ & 7.08 & 1 \\
\hline V. polyanthes & $6.72 \pm 0.74$ e & 37.22 & 2 & $91.42 \pm 2.10 \mathrm{abc}$ & 6.74 & 1 \\
\hline P. amboinicus & $7.70 \pm 0.33 d$ & 28.1 & 1 & $87.82 \pm 4.61 \mathrm{~cd}$ & 10.41 & 1 \\
\hline T. riparia & $9.44 \pm 0.14 \mathrm{~b}$ & 11.82 & 1 & $96.21 \pm 1.37 a b$ & 1.84 & 1 \\
\hline A. absinthium & $9.55 \pm 0.09 \mathrm{~b}$ & 10.74 & 1 & $97.60 \pm 1.04 \mathrm{a}$ & 0.43 & 1 \\
\hline C. citratus & $4.87 \pm 0.46 f$ & 54.54 & 2 & $86.91 \pm 5.34 \mathrm{~cd}$ & 11.33 & 1 \\
\hline Distilled water & $10.79 \pm 0.22 a$ & 0 & 1 & $98.02 \pm 0.56 a$ & 0 & 1 \\
\hline chlorpyrifos & $3.10 \pm 0.10 \mathrm{~g}$ & 71.04 & 2 & $92.26 \pm 1.19 a b c$ & 5.88 & 1 \\
\hline
\end{tabular}

Means \pm SE with the same letter in the column do not differ by Tukey's test $(P>0,05)$. ${ }^{1}$ Parasitism; ${ }^{2}$ viability; ${ }^{3}$ Reduction in viability capacity; ${ }^{4}$ Classes: 1 - innocuous ( $E<30 \%), 2$ - slightly harmful $(30 \leq E \leq 79 \%), 3$ - moderately harmful $(80 \leq E \leq 99 \%)$ and 4 - harmful $(E>99 \%)$.

in tests of selectivity as positive control of toxicity to allow for comparisons with other insecticides, due to its negative effects in Trichogramma species (STEFANello JúnIor et al. 2008; AmAro et al. 2015).

\section{Sublethal effects of botanical extracts on adults of} $T$. pretiosum. Sublethal effects may affect growth and development, by interfering in cellular metabolism (AgUIARMENEZES 2005). The reduction of egg-laying rates or inhibition are important effects of botanical extracts over insect's reproduction (COSTA et al. 2004). Analyzing the total number of parasitized eggs, in the treatments of chlorpyrifos, $C$. ambrosioides and $C$. citratus, the number of parasitized eggs was $0 ; 2.66$ and 2.08 respectively (Table 4). In treatment with chlorpyrifos, it is possible that the high toxicity of the organophosphate compounds may have interfered in the results. SouzA (2011) reported a mortality of half of the population of $T$. pretiosum after one hour of exposition to eggs treated with chlorpyrifos.
In the $C$. ambrosioides treatment, it may have happened due to the presence of ascaridole, a secondary compound. Experiments made with essential oil made from leaves and stem of C. ambrosioides, in the weevil Sitophilus zeamais Motschulsky (Coleoptera: Curculionidae), resulted in a $100 \%$ mortality rate, $24 \mathrm{~h}$ after exposition to a dose of $500 \mu \mathrm{L}$ oil/L (Jaramillo et al. 2012). The treatment C. citratus, which has citral among its secondary compounds, may have affected the amount of parasitized eggs. Experiments made with essential oils of Pelargonium graveolens and Lippia alba, which possess geraniol, linalool, carvone and citral among their major compounds, resulted in significant mortality in larvae of S. frugiperda in comparison with the natural bioinsecticide Azamax ${ }^{\circledR}$ and with the negative control (Niculau et al. 2013).

In agroecosystems, the longevity of egg-parasitoids may be influenced by several factors, such as feeding, temperature, relative humidity, as well as nutritional conditions of the hostegg (PACheco \& CorrêA-Ferreira 1998).

Table 4. Biological parameters on adults of Trichogramma pretiosum (Hymenoptera: Trichogrammatidae) under effect of the treatments.

\begin{tabular}{lcccc}
\hline \multicolumn{1}{c}{ Treatments } & \multicolumn{2}{c}{$\mathbf{N}^{\circ}$ parasitized eggs } & & Longevity (D) \\
\hline R. officinalis & $44.6 \pm 2.34$ & $\mathrm{f}$ & $3.2 \pm 0.39$ & $\mathrm{bcd}$ \\
\hline M. glomerata & $107.28 \pm 7.29$ & $\mathrm{bc}$ & $5.28 \pm 0.5$ & $\mathrm{bc}$ \\
\hline V. curassavica & $95.5 \pm 6.01$ & $\mathrm{~cd}$ & $6.16 \pm 0.57$ & $\mathrm{~b}$ \\
\hline C. ambrosioides & $2.08 \pm 1.78$ & $\mathrm{~g}$ & $3.92 \pm 0.49$ & $\mathrm{bcd}$ \\
\hline V. polyanthes & $80.71 \pm 4.83$ & $\mathrm{de}$ & $3.14 \pm 0.3$ & $\mathrm{cde}$ \\
\hline P. amboinicus & $65.44 \pm 6.97$ & $\mathrm{e}$ & $4.33 \pm 0.54$ & $\mathrm{bcd}$ \\
\hline T. riparia & $80.88 \pm 3.95$ & $\mathrm{de}$ & $3.88 \pm 0.38$ & $\mathrm{bcd}$ \\
\hline A. absinthium & $119.9 \pm 5.37$ & $\mathrm{bc}$ & $4.8 \pm 0.38$ & $\mathrm{bcd}$ \\
\hline C. citratus & $2.66 \pm 1.39$ & $\mathrm{~g}$ & $2.6 \pm 0.24$ & $\mathrm{def}$ \\
\hline Distilled water & $165.57 \pm 6.82$ & $\mathrm{a}$ & $10.42 \pm 0.57$ & $\mathrm{a}$ \\
chlorpyrifos & 0 & $\mathrm{~g}$ & $1.05 \pm 0.05$ & $\mathrm{f}$ \\
\hline
\end{tabular}

Means \pm SE with the same letter in the column do not differ by Tukey's test $(P>0,05)$.

In the present work, the parasitoid was exposed to botanical extracts in controlled laboratory conditions and it was observed alterations in female longevity, with the treatment C. citratus ( 2.6 days) being the closest one to the positive control chlorpyrifos (1.05 days). In treatment with distilled water, the duration was 10.42 days (Table 4 ), similar results to those of OlivelRA et al (2005), in which the longevity had a variation between 11 and 13 days in laboratory conditions.

The effects of botanical extracts over the parasitoid's longevity may be related to the act of parasitize. When the female parasitoid starts touching the eggs pulverized with treatments, then she starts absorbing the toxic substances (by contact) and thus causing negative effects on the longevity. For a substance to cause toxic effects in an organism biology, it has to penetrate the cells and spread, starting to interfere in physiological or biochemical processes, causing impact in longevity, growth, development, reproduction and behavior (Delpuech \& Meyet 2003). 
The satisfactory parasitism rate in laboratory rearing is around $80 \%$. In the present experiment, the distilled water reached $80 \%$ of parasitism by the $10^{\text {th }}$ day, as well as the botanical extracts of $C$. ambrosioides and $V$. polyanthes. The treatments with $A$. absinthium. $R$. oficinais, $V$. curassavica and $C$. citratus reached the $80 \%$ rate sooner than expected, when comparing with distilled water. There was an extrapolation with the extract of $M$. glomerate, which reached $80 \%$ of parasitism only by the $15^{\text {th }}$ day, contrary of $P$. ambrosioides, which reached the $80 \%$ rate by the sixth day, both treatments differing from the remaining (Figure 1).

Regarding the daily parasitism rate, the treatment with $C$. citratus differed from all the others, with approximately 15 parasitized eggs in the beginning, with several peaks of oviposition and days when there was no parasitism. The remaining treatments began with a mean of 25 parasitized eggs, then gradually diminishing over time. It was not possible to calculate the daily and accumulated parasitism rates of the positive control, chlorpyrifos, as all females died in the first 24 h (Figure 1).
According to MorelRA et al. (2005), there is a misconception that botanical extracts with insecticide activity have a smaller toxic potential and are safer than the synthetical products, when there are botanical products in the market that are toxic to fishes, pollinators, mammals, benefic insects, natural enemies, etc. In this context, researches to find botanical products that are efficient in controlling the pest, but selective to natural enemies, are especially important.

Given the results found, we conclude that the botanical extracts analyzed are innocuous (class 1 ) or slightly harmful (class 2) to $T$. pretiosum. However, it is demonstrated that $C$. citratus has small selectivity and sublethal effect on adults of T. pretiosum.

The treatments classified as class 1 may be recommended to integrated pest management programs, aiming to unite alternative and biological methods. The remaining treatments need more studies about their selectivity, which should be done in semi-field and field conditions, to confirm their toxic potential and investigate their impacts.
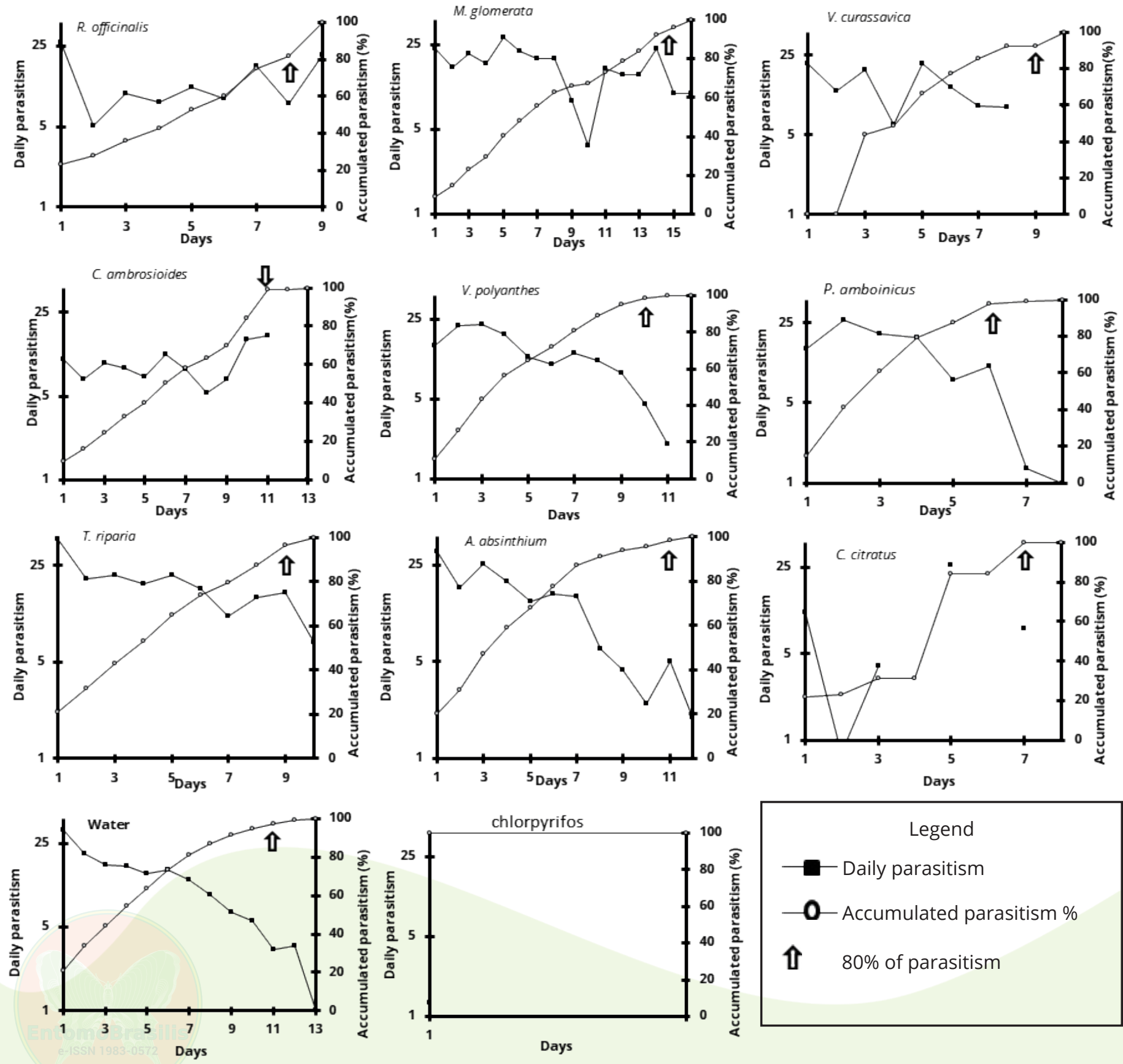
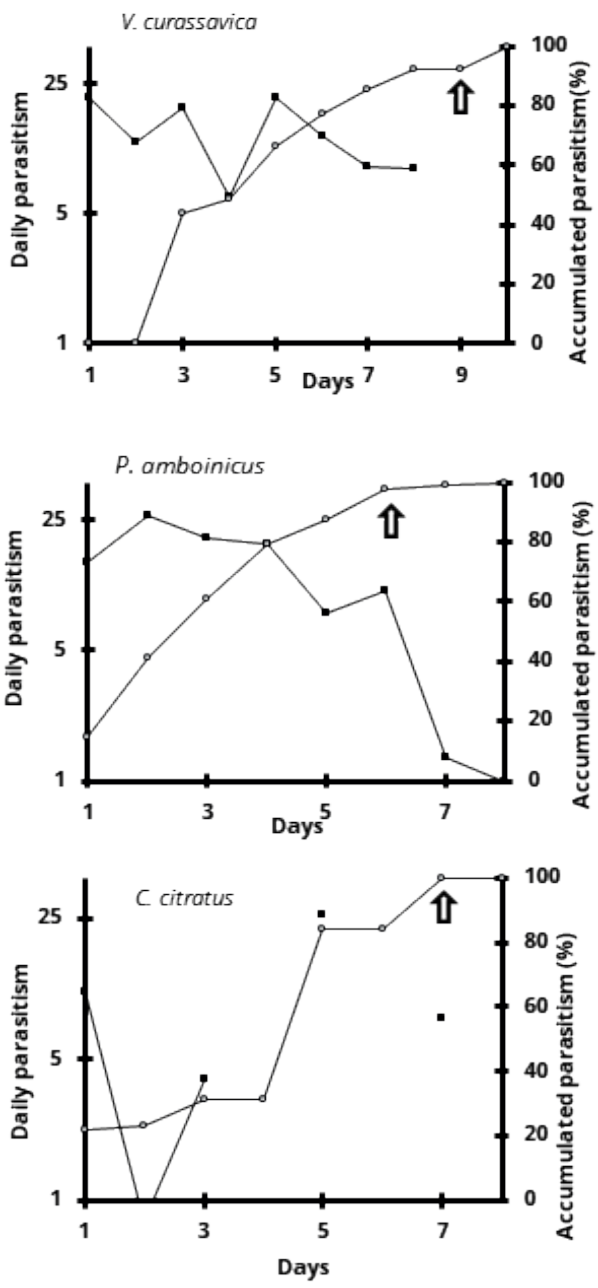

Legend

Daily parasitism

- Accumulated parasitism \%

个 $80 \%$ of parasitism

Figure 1. Daily and accumulated parasitism of Trichogramma pretiosum (Hymenoptera: Trichogrammatidae) under effect of the treatments. 


\section{REFERENCES}

Aguiar-Menezes, EL, 2005. Inseticidas botânicos: seus princípios ativos, modo de ação e uso agrícola. Embrapa Agrobiologia. Embrapa.

Amaro, JT, AF Bueno, AF Pomari-Fernandes \& PMOJ Neves, 2015. Selectivity of organic products to Trichogramma pretiosum Riley (Hymenoptera: Trichogrammatidae). Neotropical Entomology, 44: 489-497. DOI: https://doi.org/10.1007/s13744-015-0317-2

Bueno, AF \& RCOF Bueno, 2012. Integrated pest management as a tool to mitigate the pesticide negative impact into the agroecosystem: the soybean example, pp. 165-190. In: Jokanovic, M. The impact of pesticides. Cheyenne: Academy Publish.

Carriconde, C, D Mores, M Von Fritschen \& EL Cardozo Júnior, 1996. Plantas medicinais e alimentícias. Centro Nordestino de Medicina Popular, 1: 45-47.

Costa, ELN, RFP Silva \& LM Fiuza, 2004. Efeitos, aplicações e limitações de extratos de plantas inseticidas. Acta Biologica Leopoldensia, 26: 173-185.

Croft, BA, 1990. Arthropod Biological Control Agents and Pesticides. New York: Wiley.

Delpuech, JM \& J Meyet, 2003. Reduction in the sex ratio of the progeny of a parasitoid wasp (Trichogramma brassicae) surviving the insecticide chlorpyrifos. Archives of Environmental Contamination and Toxicology, 45: 203208. DOI: https://doi.org/10.1007/s00244-002-0146-2

Desneux, N, A Decourtye \& JM Delpuech, 2007. The Sublethal effects of pesticides on beneficial arthropods. Annual Review of Entomology, 52: 81-106. DOI: https://doi.org/10.1146/annurev.ento.52.110405.091440

Gonçalves-Gervásio, R de CR \& JD Vendramim, 2004. Efeito de extrato de meliáceas sobre o parasitóide de ovos Trichogramma pretiosum Riley (Hymenoptera: Trichogrammatidae). Neotropical Entomology, 33:607-612. DOI: https://doi.org/10.1590/s1519-566×2004000500010

Hassan, SA, 1992. Guidelines fortestingthe effects of pesticides on beneficials organisms: description of test methods, pp. 18-39. In: Guidelines fortestingthe effects of pesticides on beneficials organism. (Bulletin OILB/SROP).

Hassan, SA, N Halsall, AP Gray, C Kuehner, M Moll, FM Bakker, J Roembke, A Yousef, F Nasr \& HA Abdelgader, 2000. A laboratory method to evaluate the side effects of plant protection products on Trichogramma cacoeciae Marchal (Hymenoptera: Trichogrammatidae), pp 107-119. In: Candolfi, MP, S Blümel, R Forster, FM Bakker, C Grimm, SA Hassan, U Heimbach, MA Meadbriggs, B Reber, R. Schmuck \& H. Vogt, (Eds.): Guidelines to evaluate side-effects of plant protection products to non-target arthropods. Reinheim: IOBC/WPRS.

Hohmann, CL, FAC Silva \& TG Novaes, 2010. Selectivity of neem to Trichogramma pretiosum Riley and Trichogrammatoidea annulata De Santis (Hymenoptera: Trichogrammatidae). Neotropical Entomology, 39: 985990. DOI: https://doi.org/10.1590/s1519-566×2010000600021

Jaramillo BE \& WD Delgado, 2012. Bioactividad del aceite esencial de Chenopodium ambrosioides colombiano. Revista Cubana de Plantas Medicinales, 17: 54-64.

Lorenzi, H \& FJA Matos, 2008. Plantas Medicinais no Brasil: nativas e exóticas. Instituto Plantarum de Estudos da Flora Ltda.

Machado, LA, VB Silva \& MM Oliveira, 2007. Uso de extratos vegetais no controle de pragas em horticultura. O Biológico, 69: 103-106.

Manzoni, C.G., A.D. Grutzmacher, P. Giolof, C.A.B. Lima, W.R. Harter, R.V. Castilhos \& D.F. Paschoalm, 2007. Seletividade de agroquímicos utilizados na produção integrada de maçã aos parasitoides Trichogramma pretiosum Riley e Trichogramma atopovirilia Oatman \& Platner (Hymenoptera: Trichogrammatidae). Bio Assay, 2:1-11.
Martinez, SS, 2011. O nim: Azadirachta indica - natureza, usos múltiplos, produção. Instituto Agronômico do Paraná.

Medina, P, G Smagghe, F Budia, L Tirry \& E Vinuela, 2003. Toxicity and absorption of azadirachtin, diflubenzuron, pyriproxifen, and tebufenozide after topical application in predatory larvae of Chrysoperla carnea (Neuroptera: Chrysopidae). Pest Management, 32: 196-203.

Moreira, MD, MC Picanço, EM Silva, SC Moreno \& JC Martins, 2005. Uso de Inseticidas Botânicos no Controle de Pragas, pp. 90-135. In: Venezon, M, J Paula Júnior \& A Pallini (Eds.). Livro de Controle Alternativo de pragas, Epamig.

Morgan, ED, 2009. Azadirachtin, a scientific gold mine. Bioorganic Medicinal Chemistry, 17: 4096-4105. DOI: https://doi.org/10.1016/j.bmc.2008.11.081

Mossini, SAG \& CA Kemmelmeier, 2005. Árvore Nim (Azadiractha indica A. Juss): Múltiplos usos. Acta Farmaceutica Bonaerense, 1: 139-148.

Ndione, RD, O Faye, M Ndiaye, A Dieye \& JM Afoutou, 2007. Toxic effects of neem products (Azadirachta indica A. Juss) on Aedes aegypti Linnaeus 1762 larvae. African Journal of Biotechnology, 6: 2846-2854. DOI: https://doi.org/10.5897/ ajb2007.000-2454

Nerio, LS, J Olivero-Verbel \& E Stashenko, 2009. Repellent activity of essential oils: A review. Bioresource Technology, 101: 372-378. https://doi.org/10.1016/j. biortech.2009.07.048

Niculau, ES, PB Alves, PC Nogueira \& VRS Moraes, 2013. Atividade inseticida de óleos essenciais de Pelargonium graveolens l'Herit e Lippia alba (Mill) N. E. Brown sobre Spodoptera frugiperda (J. E. Smith). Química Nova, 36: 1391-1394. DOI: https://doi.org/10.1590/s010040422013000900020

Oliveira HN, CA Colombi, D Pratissoli, EP Pedruzzi \& LP Dalvi, 2005. Capacidade de parasitismo de Trichogramma exiguum Pinto \& Platner, 1978 (Hymenoptera: Trichogrammatidae) criados em dois hospedeiros por diversas gerações. Ciência e Agrotecnologia, 29: 284-288. DOI: https://doi.org/10.1590/S1413-70542005000200003

Oliveira, RC,DPratissoli\&AFBueno,2003. Efeito deAzadirachata indica (NIM) sobre o parasitismo de Trichogramma pretiosum (Hymenoptera: Trichogrammatidae) em ovos de Anasgasta kuehniella (Lepidoptera: Pyralidae). Revista Ecossistema, 28: 75-78.

Pacheco, DJP \& BS Corrêa-Ferreira, 1998. Potencial reprodutivo e longevidade do parasitoide Telenomus podisi Ashmead, em ovos de diferentes espécies de percevejos. Anais da Sociedade Entomológica do Brasil, 27: 585-591. DOI: https://doi.org/10.1590/s0301-80591998000400011

Parra, JRP, RA Zucchi, JRA Coelho, LD Geremias \& FL Cônsoli, 2015. Trichogramma as a tool for IPM in Brazil, pp. 472496. In: Vinson, B, SM Greenberg, T Liu, A Rao \& LF Volosciuk (Eds.), Augmentative Biological Control using Trichogramma spp. Current Status and Perspectives. Northwest A\&F University Press.

Querino, RB \& RA Zucchi, 2011. Guia de Identificação de Trichogramma para o Brasil. Brasília: Embrapa Informação Tecnológica.

Ribeiro, LP, STB. Dequech, DS Dhonathã, F Ferreira, CD Sausen, VS Sturza \& C Camera, 2009. Toxicidade de inseticidas botânicos sobre Eriopis connexa (Coleoptera: Coccinellidae). Revista da FZVA, 16: 246- 254.

Sidiqui, BS, F Afshan, T Gulzar, R Sultana, SN Naqvi \& RM, 2003. Tetracyclic triterpenoids from the leaves of Azadiractha indica and their insecticidal activities. Chemical Pharmaceutical Bulletin, 51: 415-417. DOI: https://doi.org/10.1248/cpb.51.415

Silva, CP, TG Riccib, AL Arruda, FM Pagliosa \& MLR Macedo, 2017. Extratos vegetais de espécies de plantas do cerrado Sul-Matogrossense com potencial de bioherbicida e bioinseticida. Uniciências, 21: 25-34. DOI: https://doi.org/10.17921/1415-5141.2017v21n1p25-34 
Silva, MPL, LS Alves \& RS Carvalho, 2010. Bioatividade de extrato aquoso de Chenopodium ambrosioides L., no controle de Toxoptera citricida (Hemiptera: Aphididae) em citros. Revista Brasileira de Agroecologia, 4: 543-545.

Soares, CSA, M Silva, MB Costa \& CES. Bezerra, 2011. Ação inseticida de óleos essenciais sobre a lagarta desfolhadora Thyrinteina arnobia (Stoll) (Lepidoptera: Geometridae). Revista Verde de Agroecologia e Desenvolvimento Sustentável, 6: 154-157.

Souza, JR, 2011. Ação de inseticidas usados na cultura do milho a Trichogramma pretiosum Riley, 1879. Dissertation (Marter in Agronomy: Entomology). Universidade Federal de Lavras, Lavras.

Stefanello Júnior, GJ, AD Grützmacher, DD Grützmacher, GO Dalmazo, MDF Paschoal \& WR Härter, 2008. Efeito de inseticidas usados na cultura do milho sobre a capacidade de parasitismo de Trichogramma pretiosum Riley, 1879 (Hymenoptera: Trichogrammatidae). Arquivos do Instituto Biológico, 75: 187-194.

Sterk, G, SA Hassan, M Baillod, F Bakker, F Bigler, S Blümel, H Bogenschütz, E Boller, B Bromand, J Brun, JNM Calis,
J Coremans-Pelseneer, C Duso, A Garrido, A Grove, U Heimbach, H Hokkanen, J Jacas, G Lewis, L Moreth, L Polgar, L Rovesti, L Samsoe-Peterson, B Sauphanor, L Schaub, A Stäubli, JJ Tuset, A Vainio, M Van de Veire, G Viggiani, E Viñuela, H Vogt, 1999, Results of the seventh joint pesticide testing programme carried out by the IOBC/WPRS- Working Group 'Pesticides and Beneficial Organisms'. BioControl, 44:99-117. DOI: https://doi.org/10.1023/A:1009959009802

Vendramim, JD \& E Castiglioni, 2000. Aleloquímicos, resistência de plantas e plantas inseticidas, pp. 113-128. In: Guedes, JC, ID Costa \& E Castiglioni (Org). Bases e técnicas do manejo de insetos. Pallotti.

Vogt, H, M Gonzalez, A Adan, G Smagghe \& E Vinuela, 1998. Efectos secundarios de la azardiractina, vía contacto residual, en larvas jóvenes del depredador Chrysoperla carnea (Stephens) (Neuroptera, Chrysopidae). Boletín de Sanidad Vegetal de Plagas, 24:67-78.

$* * * * * * * * * *$

\section{Suggestion citation:}

Gladenucci, J, JCA Pernambuco Filho, RCOF Bueno \& FPG Bonfim, 2020. Selectivity and sublethal effect of botanical extracts on adults of Trichogramma pretiosum Riley (Hymenoptera: Trichogrammatidae). EntomoBrasilis, 13: e871.

Available in: doi: 10.12741/ebrasilis.v13.e871

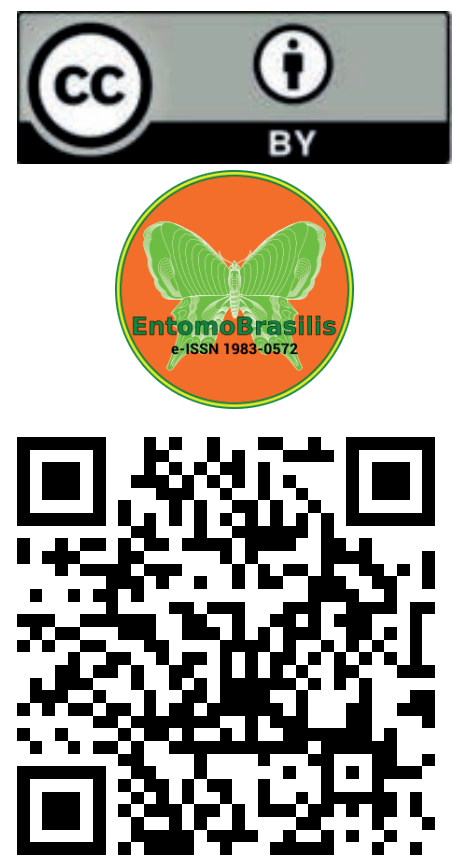

